\title{
S100A6 preferentially labels type $C$ nevus cells and nevic corpuscles: additional support for Schwannian differentiation of intradermal nevi
}

Background: Melanocytic nevi typically show a morphologic sequence of maturation from epithelioid "type A" cells to fusiform, Schwann cell-like "type C" cells with dermal descent. Nevi may also produce Wagner-Meissner-like structures (nevic corpuscles). Previous studies have shown that this maturation of intradermal nevi recapitulates intermediate stages in Schwann cell development. In intradermal nevi, we have evaluated the pattern of S100A6 protein, a form of S100 found in Schwann cells.

Methods: Formalin-fixed, paraffin-embedded archival tissues were evaluated by immunohistochemistry using antibodies specific for S100A6 and S100B in 38 intradermal nevi (IDN). Ten neurofibromas $(\mathrm{NF}), 3$ Schwannomas (SCH), 2 palisaded and encapsulated neuromas (PEN), and 2 granular cell tumors (GCT) were included as positive controls since these lesions have large numbers of Schwann cells. Results: Melanocytic nevi demonstrated preferential anti-S100A6 staining of "type C" cells (36/38; 28 strong, 8 weak) and nevic corpuscles (25/38; 19 strong, 6 weak) compared to "type A" cells (17/38; 17 weak) and "type B" cells (17/38; 4 strong, 13 weak). All NF, SCH, and PEN stained strongly with anti-S100A6. Both GCT were negative with anti-S100A6 but positive with anti-S100B.

Conclusions: The pattern of S100A6 expression in intradermal nevi further supports the hypothesis that maturation in these lesions recapitulates features of Schwann cell differentiation. The lack of S100A6 expression by both GCT suggests that these lesions have lost this feature of Schwann cells, which may play a role in their peculiar phenotypic appearance.

Fullen DR, Reed JA, Finnerty B, McNutt NS. S100A6 preferentially labels type $\mathrm{C}$ nevus cells and nevic corpuscles: additional support for Schwannian differentiation of intradermal nevi.

J Cutan Pathol 2001; 28: 393-399. (C) Munksgaard 2001.
D. R. Fullen ${ }^{1}$, J. A. Reed ${ }^{2}$, B. Finnerty ${ }^{3}$ and N. S. McNutt ${ }^{3}$

${ }^{1}$ Department of Pathology, University of Michigan Hospitals, Ann Arbor, Michigan, USA, 2Division of Dermatopathology, Department of Pathology, Baylor College of Medicine, Houston, Texas, USA, ${ }^{3}$ Division of

Dermatopathology, Department of Pathology, The New York Presbyterian Hospital-Cornell University Weill Medical College, New York, New York, USA

Douglas R. Fullen, M.D., Department of Pathology, University of Michigan Hospitals, M5230, Medical Sciences I, 1301 Catherine Street, Ann Arbor, Ml 48109-0602, USA Tel: +17347644460

Fax: +17349362756

e-mail: dfullen@umich.edu

Accepted April 3, 2001
Melanocytic nevi demonstrate morphologic "maturation" characterized by a progression from epitheliod "type A" cells in the papillary dermis to lymphocyte-like "type B" cells to Schwann-like "type C" cells with progressive descent in the dermis. ${ }^{1,2}$ Over the past century, the origin of the type $\mathrm{G}$ nevus cell has been a topic of considerable debate. Unna considered the origin of dermal nevus cells to be derived from epidermal melanocytes by a dropping off process referred to as "abtropfung". ${ }^{3}$ Yet, other investigators promoted the theory that at least some dermal nevus cells were derived from Schwann cells in the dermis, a pro- 


\section{Fullen et al.}

cess referred to as "hochsteigerung" or ascending of the cells. $^{4,5}$

Evidence in support of a melanocytic origin of dermal nevus cells is derived from ultrastructural, biochemical, and light microscopic observations. In 1965, Gottlieb et al. demonstrated the close resemblance of nevus cells to melanocytes by ultrastructural analysis. ${ }^{6}$ In 1971, Thorne et al. demonstrated tyrosinase activity in type $\mathrm{C}$ nevus cells by electron microscopy using a modified DOPA reaction. ${ }^{7}$ Moreover, age-related changes in intradermal nevi (IDN) also support a single histogenesis from melanocytes. ${ }^{8-11}$

IDN show terminal "maturation" along a Schwann cell differentiation pathway in progressing to type $\mathrm{C}$ nevus cells. Goovaerts et al. proposed that "atrophy" is a more appropriate term than maturation for this process, based on decrease in size and number of most cellular constituents, except for mitochondria and microfilaments. ${ }^{12}$ Evidence for Schwannian differentiation comes from the close resemblance of type G nevus cells to Schwann cells by light and electron microscopy, ${ }^{4,13-15}$ presence of pseudo-Meissnerian corpuscles (nevic corpuscles) in some IDN, ${ }^{4,13,16,17}$ intimate relationship between type $\mathrm{C}$ nevus cells and complex networks of small unmyelinated axons, ${ }^{4,18,19}$ and similarities in immunophenotype between type $\mathrm{C}$ nevus cells and Schwann cells. ${ }^{17,20,21}$

Immunohistochemical studies have shown that type $\mathrm{G}$ nevus cells recapitulate Schwann cells in an intermediate stage of differentiation, i.e. lack the ability to produce and maintain myelin. Aso et al. demonstrated expression of a Schwann cell-associated protein (AHMY-1), which reacted with $\mathrm{P} 0$ and $\mathrm{P} 1$ myelin proteins and myelin basic protein but not $\mathrm{P} 2$ myelin protein, in both type $\mathrm{C}$ nevus cells and nevic corpuscles $(\mathrm{NC}) .{ }^{17}$ Some authors have shown that type $\mathrm{C}$ nevus cells do not express myelin basic protein, a feature of terminally differentiated Schwann cells, by immunohistochemistry. ${ }^{22,23}$ Reed et al. showed that type $\mathrm{C}$ nevus cells and $\mathrm{NC}$ adopted an intermediate, "premyelinating/promyelinating" Schwann cell phenotype based on expression of lowaffinity nerve growth factor receptor (p75-NGFR), neural cell adhesion molecule (N-CAM/CD56), and growth-associated phosphoprotein-43 (GAP-43). ${ }^{21}$ Prieto et al. demonstrated the relationship of small axons to type $\mathrm{C}$ nevus cells and NC using an antibody to the intermediate filament peripherin $;{ }^{24}$ however, the type $\mathrm{C}$ nevus cells and $\mathrm{NG}$ did not label with peripherin. ${ }^{24,25}$ Argenyi et al. demonstrated strong p75-NGFR expression in NC, as well as in type $\mathrm{C}$ nevus cells, and suggested that nerve growth factor was important in development of NC, and that "neural differentiation" was a feature seen in some longstanding nevi. ${ }^{26}$

Ultrastructurally, type $\mathrm{C}$ nevus cells show similar features to spindle cells associated with $\mathrm{NC}$, i.e. spindle cells possessing abundant cytoplasmic intermediate filaments, discontinuous basal lamina, and frequent pinocytotic vesicles. ${ }^{17,27} \mathrm{NC}$ have laminated cytoplasmic structures and, therefore, closely resemble Wagner-Meissner tactile bodies of the skin. ${ }^{16,28,29}$

S100 protein is strongly expressed by cells of neural crest origin, including melanocytes, Schwann cells, and NC. ${ }^{30-34}$ Since the original isolation of $\mathrm{S} 100$ protein, a mixture of predominantly $\mathrm{S} 100 \mathrm{~B}$ and a lesser amount of S100A1, from bovine brain extracts by Moore in $1965,{ }^{35}$ several other $\mathrm{S} 100$ calcium-binding proteins have been discovered. ${ }^{36,37}$ S100A6 protein, a.k.a. calcyclin, was discovered in 1986 by Calabretta et al. ${ }^{38}$ This protein has been isolated from a variety of normal cell types, including melanocytes, Schwann cells and Schwann-like cells, Langerhans' cells, dermal dendrocytes, some glandular epithelium, and keratinocytes (weak). ${ }^{39-43}$ Some melanocytic nevi express S100A6 protein by immunohistochemistry. ${ }^{44}$

Since S100A6 protein has been reported in some melanocytic nevi and Schwann cells, we evaluated the pattern of S100A6 protein expression in IDN by immunohistochemistry to determine if the staining pattern supports terminal differentiation along a Schwann cell pathway. In addition, we evaluated a variety of neural tumors thought to have a prominent Schwann cell component to see if there was any difference in their expression of S100A6 protein.

\section{Material and methods}

Cases of IDN (38), neurofibroma (NF) (10), Schwannoma (SCH) (3), solitary circumscribed neuroma/palisaded encapsulated neuroma (PEN) (2), and granular cell tumor (GCT) (2) were retrieved from the Dermatopathology Service and Archives at the New York Hospital-Cornell University Weill Medical College during the period of July 1998 to July 1999. IDN that possessed spindled cells in the deep dermis or had NC were specifically sought for inclusion in the study.

Formalin-fixed, paraffin-embedded tissue sections, approximately $4 \mu$ thick, were placed on charged (plus), gray-frosted, $75 \mu$ capillary gap ChemMate/ BioTek slides (Ventana Medical Systems Inc., Tuscon, AZ, USA). A 1-h capillary action-based immunohistochemical technique was employed as described previously. ${ }^{45}$ The sections were deparaffinized, rehydrated and treated with pepsin for $10 \mathrm{~min}$ at $45^{\circ} \mathrm{C}$. Endogenous phosphatases were blocked using glacial acetic acid $(1 \%)$ for $10 \mathrm{~min}$ at room temperature. Primary antibodies to S100A6/clone CACY-100 (1:1000, mouse monoclonal; Sigma, St. Louis, MO, USA) and S100B (1:1000, rabbit polyclonal; Dako, Carpinteria, CA, USA) were applied to serial tissue sections. Bound primary antibodies were detected 

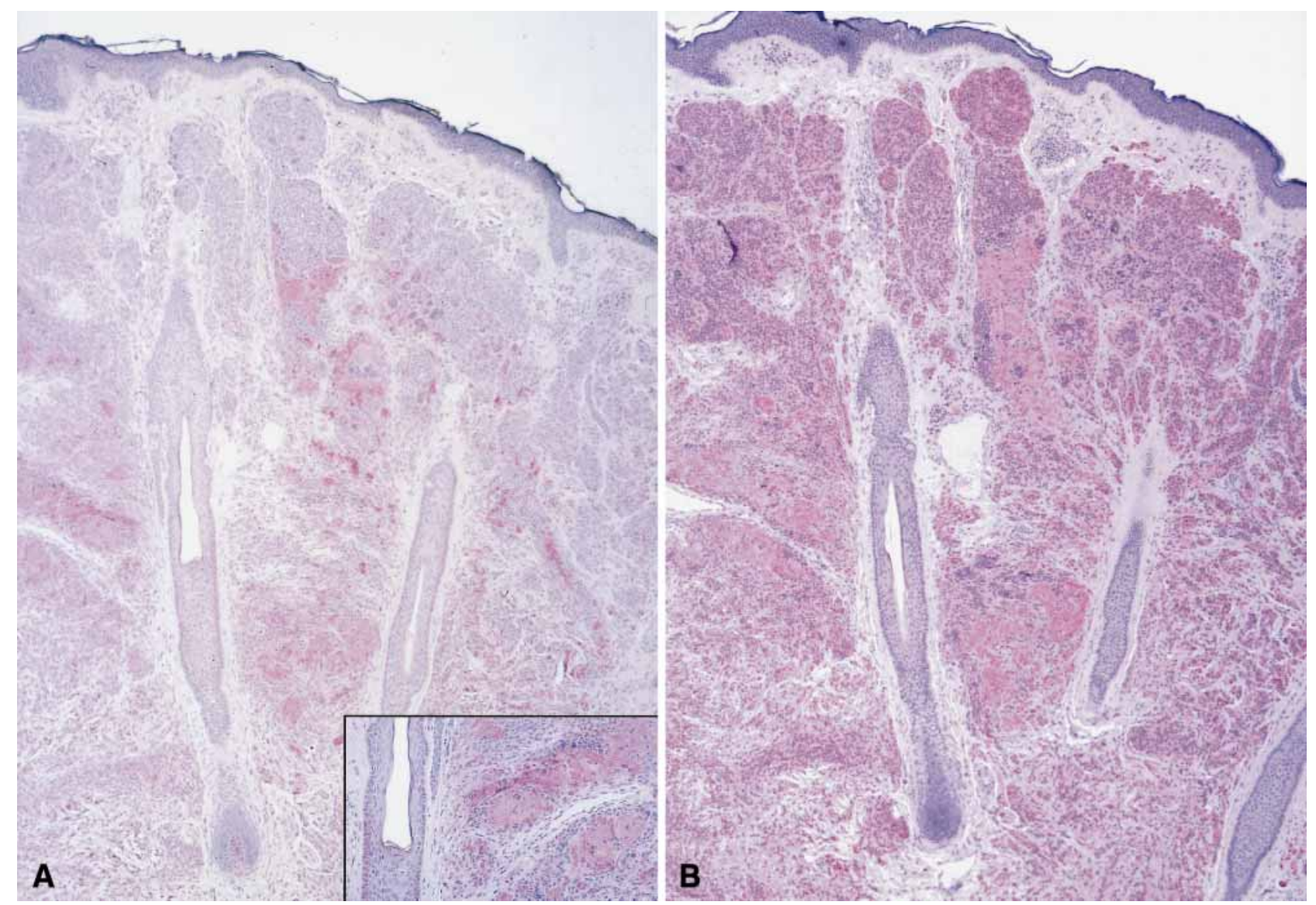

Fig. 1. Preferential labeling of type C nevus cells and nevic corpuscles (inset) with anti-S100A6 (A) compared to more diffuse labeling of type A-C cells and nevic corpuscles with anti-S100B (B).

using an streptavidin-alkaline phosphatase system. The complexes were visualized with red chromogen (SK-5100 kit; Vector Labs, Burlingame, CA, USA). Tissue sections were counterstained with hematoxylin.

The different tissues were compared with respect to types of cells stained and patterns of staining. Immunolabeling was determined to be present $(+)$ or absent (-). Positive staining was then semiquantitatively graded as weak $(1+)$ or strong $(2+)$. The staining patterns were interpreted by two of the authors (J.A.R. and D.R.F.).

Chi-square analysis was performed using Sigma Stat software (Jandel Scientific, San Raphael, CA, USA) run on a PC. Statistical significance was assigned to a $\mathrm{p}<0.05$ value.

\section{Results}

Thirty-six of $38(95 \%)$ IDN showed S100A6 protein expression by type $\mathrm{C}$ nevus cells (28 strong, 8 weak) in the deep portion of the dermal component. In contrast, 17 of $38(45 \%)$ type A (0 strong, 17 weak) and 17 of $38(45 \%)$ type B (4 strong, 13 weak) nevus cells showed S100A6 protein expression in the upper and middle portions of the dermal component, respectively (Fig. 1). The preferential S100A6 labeling of type $\mathrm{C}$ nevus cells compared to types $\mathrm{A}$ and $\mathrm{B}$ nevus cells achieved statistical significance $(\mathrm{p}<0.001)$.

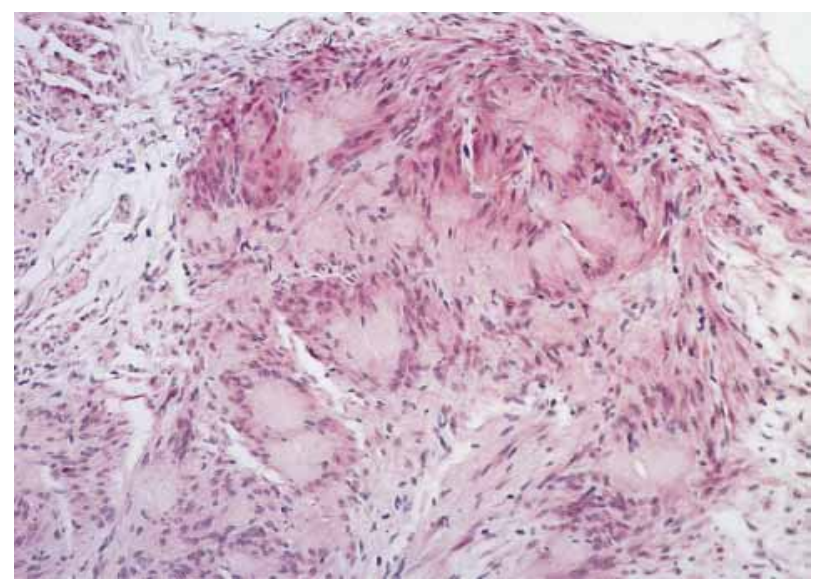

Fig. 2. Diffuse and strong labeling of Schwann cells and Verocay bodies in a Schwannoma. 


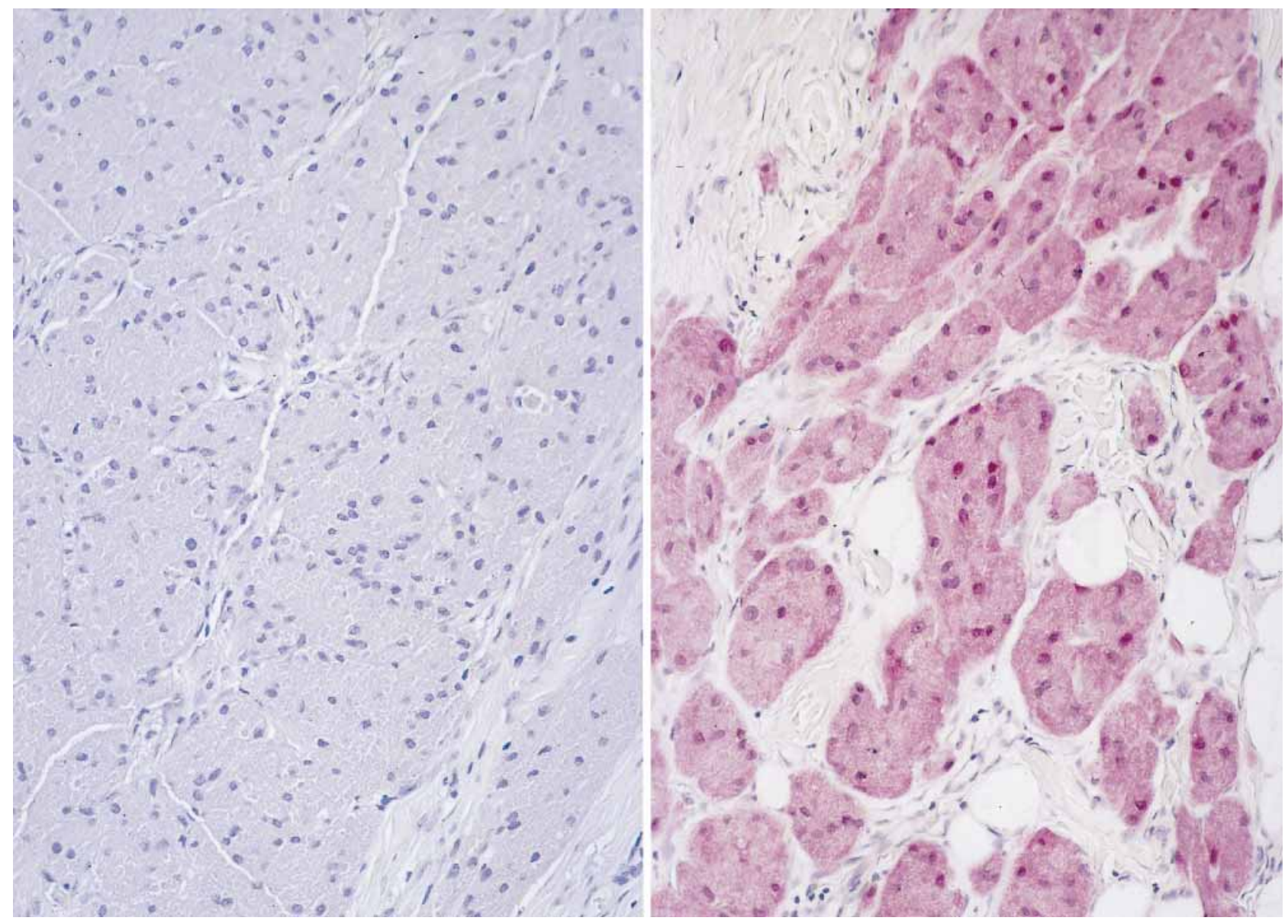

Fig. 3. Granular cell tumor showing absence of labeling with anti-S100A6 (left) but strong labeling with anti-S100B (right).

NG in 25 of 38 IDN $(66 \%)$ showed positive staining (19 strong, 6 weak) with anti-S100A6 compared to type A $(45 \%)$ or type B $(45 \%)$ nevus cells (Fig. 1). This difference did not reach statistical significance $(p=$ $0.106)$, probably due to the lack of $\mathrm{NC}$ in 11 of 38 $(29 \%)$ IDN. Two cases with NC did not stain with anti-S100A6, but also did not have any staining with anti-S100B.

All 10 NF, 3 SCH, and 2 PEN demonstrated strong and diffuse positivity of the vast majority of spindled cells in the tumors (Fig. 2). Interestingly, both GCT did not label with anti-S100A6, but, as expected, showed strong and diffuse staining with anti-S100B (Fig. 3). On hematoxylin and eosin (H\&E)-stained sections, the polygonal tumor cells had small central nuclei and abundant eosinophilic granular cytoplasm, as is typical of a GCT. The S100B protein expression excludes that either tumor is a fibrohistiocytic or smooth muscle tumor with granular cell change.

\section{Discussion}

Neural tumors, characterized by the presence of many Schwann cells, strongly expressed S100A6 cal- cium-binding protein in our study. This finding is not surprising considering previous reports of increased calcyclin gene expression in Schwann-like cells in neuroblastoma cell lines ${ }^{42}$ and Schwann cells of the rat nervous system. ${ }^{43}$ The exception to these results was the absence of anti-S100A6 labeling of either GCT.

The histogenesis of the GCT has been debated for many years. In recent years, clinical, histological, immunohistochemical (S100B expression), and ultrastructural evidence has accumulated in support of a neural origin for the vast majority of GCT. ${ }^{46-66}$ However, the exact neural cell from which the GCT is derived has remained elusive. Some observers have proposed that these tumors arise from the Schwann cell, ${ }^{59-61}$ whereas other observers support an origin from the perineurial fibroblast, ${ }^{67}$ or an undifferentiated mesenchymal cell. ${ }^{68,69}$ We have demonstrated, albeit in only two cases, that S100A6, which is commonly expressed by Schwann cells, is not present in GCT. This immunophenotype finding in our GCT is in keeping with other immunophenotypic findings that are peculiar for terminally differentiated Schwann cells. ${ }^{51,64,65,70,71}$ Additional studies includ- 


\section{Schwannian differentiation of intradermal nevi}

ing a broader panel of antibodies on a larger number of GCT may shed light on whether these tumors are derived from modified Schwann cells or some, as yet, uncharacterized cell of the peripheral nerve sheath.

The preferential S100A6 expression of type C (vs. type A and B) nevus cells demonstrated in this study is additional support for terminal maturation of IDN along a Schwann cell pathway of differentiation. In addition, we demonstrated a tendency toward strong labeling of $\mathrm{NC}$ (Wagner-Meissner-like corpuscles) with anti-S100A6, a feature also consistent with Schwann cell differentiation.

The presence of some S100A6 labeling of type A and $\mathrm{B}$ nevus cells in IDN is clear evidence that melanocytes express S100A6 protein and is consistent with the previous observation by Böni et al. ${ }^{39}$ The pattern of S100A6 protein expression compared to $\mathrm{S} 100 \mathrm{~B}$ expression in IDN lends further support to the opinion that dermal nevus cells are derived from nevomelanocytes in the epidermis. Moreover, some IDN, especially those of long-standing duration, demonstrate a predictable sequence of "maturation" in the dermis that terminates with type $\mathrm{C}$ nevus cells. These type $\mathrm{C}$ nevus cells share many phenotypic and ultrastructural features with an intermediate stage Schwann cell. ${ }^{4,13-15,17,20-23}$

In summary, we present compelling evidence, through differential patterns of expression of two S100 proteins, that the maturation of some melanocytic nevi recapitulates features of Schwann cell differentiation. In addition, this is the first report, to our knowledge, that demonstrates S100A6 protein expression in a variety of neural tumors of putative Schwann cell origin by immunohistochemistry. The absence of S100A6 protein expression by both GCT suggests that these lesions have lost this feature of Schwann cells, which is in keeping with other phenotypic findings that are peculiar for terminally differentiated Schwann cells.

\section{References}

1. Meischer G, von Albertini A. Histologie de 100 de naevipigmentaires d'après les methodes de Masson. Bull Soc Fr Dermatol Syph 1935; 42: 1265.

2. Ainsworth AM, Folberg R, Reed RJ, Clark WH Jr. Melanocytic nevi, melanocytes, melanocytic dysplasia and common forms of melanoma. In: Clark WH Jr, Goldman LI, Mastrangelo MJ, eds. Human malignant melanoma. New York: Grune \& Stratton, 1979; 167

3. Unna PG. Naevi and naevocarcinome. Berl Klin Wochenschr 1893; 30: 14.

4. Masson P. My concept of cellular nevi. Cancer 1951; 4: 9.

5. Cramer SF. The origin of epidermal melanocytes: implications for the histogenesis of nevi and melanomas. Arch Pathol Lab Med 1991; 115: 115.

6. Gottleib B, Brown AL, Winkelmann RK. Fine structure of the nevus cell. Arch Derm 1965; 92: 81.
7. Thorne EG, Mottaz JH, Zelickson AS. Tyrosinase activity in dermal nevus cells. Arch Dermatol 1971; 104: 619.

8. Lund HZ, Stobbe GD. The natural history of the pigmented nevus; factors of age and anatomic location. Am J Pathol 1949; 25: 1117.

9. Stegmaier OC. Natural regression of the melanocytic nevus. J Invest Dermatol 1959; 32: 413.

10. Maize J, Foster G. Age-related changes in melanocytic naevi. Clin Exp Dermatol 1979; 4: 49

11. Hu F. Aging of melanocytes. J Invest Dermatol 1979; 73: 70.

12. Goovaerts G, Buyssens N. Nevus cell maturation or atrophy? Am J Dermatopathol 1988; 10: 20.

13. Krüke W. Pathologie peripherer nerven. In: Olivecrona $\mathrm{H}$, Tönnis W, Krekel W, eds. Handbuch der Neurochirurgie. Berlin: Springer, 1974; 1.

14. Niizuma K. Electron microscopic study of nevic corpuscles. Acta Derm Venereol 1975; 55: 283.

15. Jurecka W, Lassmann H, Gebhart W. The relation of nervous elements to intradermal nevi: an electron microscopic study. Arch Dermatol 1978; 261: 219.

16. Pool RS. An electron microscopic study of the nevic corpuscle. Arch Pathol 1965; 80: 461.

17. Yang P, Hirose T, Hasegawa T, Seki K, Nakanishi H, Hizawa K. Ultrastructural heterogeneity of acquired intradermal melanocytic nevus cells. Ultrastruct Pathol 1996; 20: 255.

18. Bröcker EB, Magiera H, Herlyn M. Nerve growth and expression of receptors for nerve growth factor in tumors of melanocyte origin. J Invest Dermatol 1991; 96: 662.

19. Yang P, Hasegawa T, Hirose T, Hizawa K. The innervation of intradermal nevi: on the nevus-axon relations. Zentralbl Pathol 1993; 139: 295.

20. Aso M, Hashimoto K, Eto H, et al. Expression of Schwann cell characteristics in pigmented nevus. Cancer 1988; 63: 938.

21. Reed JA, Finnerty B, Albino AP. Divergent cellular differentiation pathways during the invasive stage of cutaneous malignant melanoma progression. Am J Pathol 1999; 155: 549.

22. Penneys NS, Mogollon R, Kowalczyk A, Nadji M, Adachi K. A survey of cutaneous neural lesions for the presence of myelin basic protein. An immunohistochemical study. Arch Dermatol 1984; 120: 210.

23. Gray MH, Smoller BR, McNutt NS, Hsu A. Neurofibromas and neurotized melanocytic nevi are immunohistochemically distinct neoplasms. Am J Dermatopathol 1990; 12: 234.

24. Prieto VG, McNutt NS, Lugo J, Reed JA. Differential expression of the intermediate filament peripherin in cutaneous neural lesions and neurotized melanocytic nevi. Am J Surg Pathol 1997; 21: 1450.

25. Prieto VG, McNutt NS, Lugo J, Reed JA. The intermediate filament peripherin is expressed in cutaneous melanocytic lesions. J Cutan Pathol 1997; 24: 145.

26. Argenyi ZB, Rodgers J, Wick M. Expression of nerve growth factor and epidermal growth factor receptors in neural nevi with nevic corpuscles. Am J Dermatopathol 1996; 18: 460.

27. Weiser G. Neurofibrom and perineuralzelle. Virchows Arch 1978; 379: 73.

28. Masson P. Les naevi pigmentaires, tumeurs nerveuses. Ann Ant Patol Med Chir (Paris) 1926: 417, 657

29. Cauna N, Ross LL. The fine structure of Meissner's touch corpuscles of human fingers. J Biophys Biochem Cytol 1960; 8: 467 .

30. Iwanaga T, Fujita Y, Takahashi Y, Nakajima T. Meissner's and pacinian corpuscles as studied by immunohistochemistry 
for S-100 protein, neuron-specific enolase and neurofilament protein. Neurosci Lett 1982; 31: 117.

31. Nakajima T, Watanabe S, Sato Y, Kameya T, Hirota T, Shimosata Y. An immunoperoxidase study of S-100 protein distribution in normal and neoplastic tissues. Am J Surg Pathol 1982; 6: 715.

32. Shiurba RA, Eng LF, Urich H. The structure of pseudomeissnerian corpuscles: an immunohistochemical study. Acta Neuropathol 1984; 63: 174.

33. Palazzo J, Duray PH. Typical, dysplastic, congenital, and Spitz nevi: a comparative immunohistochemical study. Hum Pathol 1989; 20: 341.

34. Van Paesschen MA, Goovaerts G, Buyssens N. A study of the so-called neurotization of nevi. Am J Dermatopathol 1990; 12: 242.

35. Moore BW. A soluble protein characteristic of the nervous system. Biochem Biophys Res Commun 1965; 19: 739.

36. Schäfer BW, Heizmann CW. The S100 family of EF-hand calcium-binding proteins: functions and pathology. Trends Biochem Sci 1996; 21: 134.

37. McNutt NS. The S100 family of multipurpose calcium-binding proteins. J Cutan Pathol 1998; 25: 521.

38. Calabretta B, Battini R, Kaczmarek L, de Riel JK, Baserga R. Molecular cloning of the cDNA for a growth factor-inducible gene with strong homology to S-100, a calcium-binding protein. J Biol Chem 1986; 261: 12628.

39. Böni R, Burg G, Doguoglu A, et al. Immunohistochemical localization of the $\mathrm{Ca} 2+$ binding $\mathrm{S} 100$ proteins in normal human skin and melanocytic lesions. BrJ Dermatol 1997; 137: 39.

40. Kuźnicki J, Kordowska J, Puzianowska M, Woźniewicz BM. Calcyclin as a marker of human epithelial cells and fibroblasts. Exp Cell Res 1992; 200: 425.

41. Kuźnicki J, Filipek A, Heimann P, Kaczmarek L, Kamińska B. Tissue-specific distribution of calcyclin $10.5 \mathrm{kDa} \mathrm{Ca} 2+-$ binding protein. FEBS Lett 1989; 254: 141.

42. Tonini GP, Casalaro A, Cara A, DiMartino D. Inducible expression of calcyclin, a gene with strong homology to s-100 protein, during neuroblastoma cell differentiation and its prevalent expression in Schwann-like cells. Cancer Res 1991; 51: 1733.

43. Yamashita N, Ilg EC, Schäfer BW, Heizmann CW, Kosaka T. Distribution of a specific calcium-binding protein of the S100 protein family, S100A6 (calcyclin), in subpopulations of neurons and glial cells of the adult rat nervous system. J Comp Neurol 1999; 404: 235.

44. Böni R, Heizmann CW, Doguoglu A, et al. Ca(2+)-binding proteins S100A6 and S100B in primary cutaneous melanoma. J Cutan Pathol 1997; 24: 76.

45. Reed JA, Manahan LJ, Park CS, Brigati DJ. Complete onehour immunocytochemistry based on capillary action. Biotechniques 1992; 13: 434.

46. Chimelli L, Symon L, Scaravilli F. Granular cell tumor of the fifth cranial nerve: further evidence for Schwann cell origin. J Neuropathol Exp Neurol 1984; 43: 634.

47. Carvalho GA, Lindeke A, Tatagiba M, Ostertag H, Samli M. Cranial granular cell tumor of trigeminal nerve: case report. J Neurosurg 1994; 81: 795.

48. May M, Beckford NS, Bedetti CD. Granular cell tumor of facial nerve diagnosed at surgery for idiopathic facial paralysis. Otolaryngol Head Neck Surg 1985; 93: 122

49. Nakazato Y, Ishizeki J, Tkahashi K, Yamaguchi H. Immuno- histochemical localization of S-100 protein in granular cell myoblastoma. Cancer 1982; 49: 1624.

50. Stefansson K, Wollmann RL. S-100 protein in granular cell tumors (granular cell myoblastomas). Cancer 1982; 49: 1834.

51. Armin A, Connelly EM, Rowden G. An immunoperoxidase investigation of S-100 protein in granular cell myoblastomas: evidence for Schwann cell derivation. Am J Clin Pathol 1983; 79: 37.

52. Seo IS, Azarelli B, Warner TF, Coheen MP, Senteney GE. Multiple visceral and cutaneous granular cell tumors. Ultrastructural and immunocytochemical evidence of Schwann cell origin. Cancer 1984; 53: 2104.

53. Mazur MT, Schultz JJ, Myers JL. Granular cell tumor. Immunohistochemical analysis of 21 benign tumors and one malignant tumor. Arch Pathol Lab Med 1990; 114: 692.

54. Weber-Chappuis K, Widmann JJ, Kapanci Y. Histologic and immunohistochemical profiles of benign granular cell tumors. Report of 41 cases. Ann Pathol 1995; 15: 198.

55. Barrande G, Kujas M, Gancel A, et al. Granular cell tumors. Rare tumors of the neurohypophysis. Presse Med 1995; 24: 1376.

56. Kaiserling E, Ruck P, Xiao JC. Congenital epulis and granular cell tumor: a histologic and immunohistochemical study. Oral Surg Oral Med Oral Pathol Oral Radiol Endod 1995; 80: 687.

57. Filie AC, Lage JM, Azumi N. Immunoreactivity of S100 protein, alpha-1-antitrypsin, and CD68 in adult and congenital granular cell tumors. Mod Pathol 1996; 9: 888.

58. Billeret-Lebranchu V, Martin de la Salle E, Vandenhaute B, Lecomte-Houcke M. Granular cell tumor and congenital epulis. Histochemical and immunohistochemical of 58 cases. Arch Anat Cytol Pathol 1999; 47: 31.

59. Fust JA, Custer RP. On the neurogenesis of so-called granular cell myoblastoma. Am J Clin Pathol 1949; 19: 522.

60. Fisher ER, Wechsler H. Granular cell myoblastoma: misnomer. Electron microscopy and histochemical evidence concerning its Schwann cell derivation and nature (granular cell Schwannoma). Cancer 1962; 15: 936.

61. Sobel HJ, Marquet M, Arvin E, Schwarz R. Granular cell myoblastoma. An electron microscopic and cytochemical study illustrating the genesis of granules, and aging of myoblastoma cells. Am J Pathol 1971; 65: 59.

62. Bedetti CD, Martinez AJ, Baeckford NS, May M. Granular cell tumor arising in myelinated peripheral nerves. Light and electron microscopy and immunoperoxidase study. Virchows Arch 1983; 402: 175.

63. Ordóñez NG, Mackay B. Granular cell tumor: a review of the pathology and histogenesis. Ultrastruct Pathol 1999; 23: 207.

64. Miettinen M, Lehtonen E, Lehtola H, Ekblom P, Lehto VP, Virtanen I. Histogenesis of granular cell tumor - an immunohistochemical and ultrastructural study. J Pathol 1984; 142: 221.

65. Buley ID, Gatter KC, Kelly PM, Heryet A, Millard PR. Granular cell tumors revisited. An immunohistological and ultrastructural study. Histopathology 1988; 12: 263.

66. Mukai M. Immunohistochemical localization of S-100 protein and peripheral nerve myelin proteins ( $\mathrm{P} 2$ protein; $\mathrm{P} 0$ protein) in granular cell tumors. Am J Pathol 1983; 112: 139.

67. Pearse AG. The histogenesis of granular cell myoblastoma (granular cell perineural fibroblastoma). J Pathol Bacteriol 1950; 62: 351.

68. Aparicio SR, Lumsden CE. Light and electron microscopic 


\section{Schwannian differentiation of intradermal nevi}

studies on the granular cell myoblastoma of the tongue. J Pathol 1969; 97: 339.

69. Regezi JA, Batsakis JG, Courtney RM. Granular cell tumors of the head and neck. J Oral Surg 1979; 37: 402.

70. Clark HB, Minesky JJ, Agrawal D, Agrawal HC. Myelin basic protein and $\mathrm{P} 2$ protein are not immunohistochemical markers for Schwann cell neoplasms. A comparative study using antisera to S-100, P2, and myelin basic proteins. Am J Pathol 1985; 121: 96 .

71. Williams HK, Williams DM. Oral granular cell tumors: a histological and immunocytochemical study. J Oral Pathol Med 1997; 26: 164 . 